\title{
AT-TARBAWI
}

At-Tarbawi: Jurnal Pendidikan, Sosial dan Kebudayaan

Volume 6 Nomor 1 Tahun 2019

doi: 10.32505/tarbawi.v6i1.1026

\section{Analisa Kompetensi Alumni Pendidikan Matematika menggunakan Discrapancy Evaluation Model}

\author{
Rita Sari ${ }^{1}$; Srimuliati ${ }^{2}$ \\ IAIN Langsa ${ }^{12}$ \\ ritasari17@iainlangsa.ac.id; srimuliati@iainlangsa.ac.id
}

\begin{abstract}
The curriculum is an important element in education and the basic framework is also an indicator of the progress of education. So important was the curriculum that the Government continuously continued to make curriculum changes from 1975 to the present. Therefore every educational institution must have a curriculum including LAIN IAIN as one of the Universities that produce prospective educators especially mathematics teachers at the level of junior and senior high school education units in Langsa city. But in reality, there are a lot of PMA Study Program alumni who work not following their scientific fields. The purpose of this study was to determine the design of PMA Study Program curriculum in meeting the needs of the labour market for alumni. This study uses discrepancy evaluation models (DEM). The results showed that stakeholders considered that a portion of PMA Study Program alumni was less competent at work. so it is necessary to do a curriculum change, especially in the distribution of subjects by taking into account the curriculum needs of the school level and the job market.
\end{abstract}

Keywords: Competence, Alumni, Stakeholders, and Discrepancy Evaluation Models.

\begin{abstract}
Abstrak
Kurikulum merupakan unsur penting dalam pendidikan dan kerangka dasar juga sebagai indikator dari kemajuan pendidikan. Begitu pentingnya kurikulum sehingga Pemerintah secara kontinu terus melakukan perubahan kurikulum sejak tahun 1975 sampai dengan sekarang. Oleh sebab itu setiap institusi pendidikan wajib memiliki kurikulum termasuk IAIN Langsa sebagai salah satu Perguruan Tinggi yang menghasilkan calon pendidik khususnya guru matematika pada tingkat satuan pendidikan SMP dan SMA di kota Langsa. Namun pada kenyataannya banyak sekali alumni Prodi PMA yang bekerja tidak sesuai dengan bidang keilmuannya. Tujuan penelitian ini adalah untuk mengetahui rancangan kurikulum Prodi PMA dalam memenuhi kebutuhan pasar kerja untuk alumninya. Penelitian ini menggunakan discrapancy evaluation models (DEM). Hasil penelitian menunjukkan bahwa stakeholder menilai bahwa sebahagian alumni Prodi PMA kurang kompeten dalam bekerja. Sehingga perlu dilakukan sebuah perubahan kurikulum terutama pada sebaran mata kuliah dengan memperhatikan kebutuhan kurikulum tingkat sekolah dan pasar kerja.
\end{abstract}

Kata Kunci: Kompetensi, Alumni, Stakeholder, dan Discrapancy Evalution Model. 


\section{A. Pendahuluan}

Kurikulum merupakan salah satu indikator majunya suatu pendidikan. Sebagai kerangka dasar dari struktur pendidikan tinggi, kurikulum dikembangkan oleh perguruan tinggi yang bersangkutan dengan mengacu pada standar nasional pendidikan untuk setiap program studi (UU No 20 Tahun 2003 Pasal 38 ayat 1 dan ayat 2 tentang Kurikulum). Kurikulum sebagai suatu rencana disusun untuk melancarkan proses belajar mengajar di bawah bimbingan dan tanggung jawab sekolah atau lembaga pendidikan beserta staf pengajarnya (Ali, 2012).

Kurikulum adalah suatu program pendidikan yang berisikan berbagai bahan ajar dan pengalaman belajar yang diprogramkan, direncanakan dan dirancangkan secara sistemik atas dasar norma-norma yang berlaku yang dijadikan pedoman dalam proses pembelajaran bagi tenaga kependidikan dan peserta didik untuk mencapai tujuan pendidikan (Dakir, 2004).

Jadi kurikulum dapat didesain dan dikembangkan oleh lembaga pendidikan untuk kepentingan pendidikan, terutama untuk mempersiapkan peserta didiknya agar mampu menyesuaikan diridan bertahan dengan perubahan serta perkembangan di dalam masyarakat digital. Sehingga sebaiknya kurikulum tidak hanya berisi tentang tujuan pendidikan saja tetapi memuat berbagai pengalaman belajar yang perlu dimiliki oleh peserta didik serta mengajarkan mereka bagaimana cara menerapkan pengalaman itu sendiri. Mengingat betapa pentingnya kurikulum dalam pendidikan dan dalam kehidupan, maka dalam menyusun kurikulum harus memahami konsep dasar dari kurikulum itu sendiri.

Institut Agama Islam Negeri (IAIN) Langsa sebagai salah satu perguruan tinggi tentunya memiliki kurikulum yang dikenal dengan Kerangka Kurikulum Nasional Indonesia (KKNI). Salah satu bentuk perubahan kurikulum dimulai dari merumuskan ide yang dituangkan dalam bentuk visi, misi dan program yang terukur dan lebih mengedepankan kebutuhan sekarang dan masa akan datang. Dan hal tersebut telah dijawab pada implementasi kurikulum berbasis KKNI di setiap Program Studi (Sugiharto, 2013). 
IAIN Langsa adalah perguruan tinggi yang menghasilkan calon-calon guru, salah satunya adalah guru pendidikan matematika di bawah naungan Program Studi Pendidikan Matematika (Prodi PMA) pada Fakultas Tarbiyah dan Ilmu Keguruan (FTIK). Sejak didirikan pada tahun 2008 sampai dengan sekarang, Prodi PMA telah mewisuda lulusan sebanyak 865 orang mahasiswa. Data ini diperolah dari hasil wawancara langsung kepada Ketua Prodi dan Sekretaris Prodi PMA FTIK IAIN Langsa.

Kompetensi memiliki pengertian sebagai suatu kekuasaan untuk menentukan atau memutuskan sebuah perkara (Purwadarminto, 2003). Sementara Mulyasa (2004) menjelaskan bahwa kompetensi merupakan perpaduan dari pengetahuan, keterampilan, nilai dan sikap yang direfleksikan dalam kebiasaan berpikir dan bertindak. Lebih jauh pada sistem pengajaran, kompetensi digunakan untuk mendeskripsikan kemampuan profesional yaitu kemampuan untuk menunjukkan pengetahuan dan konseptualisasi pada tingkat yang lebih tinggi. Pendapat tersebut diperkuat dengan Undang-Undang Nomor 14 Tahun 2005 tentang Guru dan Dosen yang mendeskripsikan bahwa"kompetensi adalah seperangkat pengetahuan, keterampilan, dan perilaku yang harus dimiliki, dihayati dan dikuasai oleh guru atau dosen dalam melaksanakan tugas keprofesionalan". Jadi dapat dipahami bahwa kompetensi adalah kemampuan yang dimiliki secara personal mencakup pengetahuan, keterampilan, nilai, dan sikap terhadap suatu bidang yang menjadi tugas khususnya.

Kompetensi guru berkaitan dengan kewajibannya melaksanakan tugas dalam bidang pengajaran yang memiliki peran sebagai alat pendidikan(Djohar, 2006). Menurut Peraturan Menteri Pendidikan Nasional Republik Indonesia Nomor 16 Tahun 2007 bahwa"kompetensi yang harus dimiliki oleh tenaga guru antara lain: kompetensi pedagogik, kepribadian, profesional dan sosial yang diperoleh melalui pendidikan profesi". Keempat kompetensi tersebut dapat dijelaskan sebagai berikut:

1) Kompetensi Pedagogik. Kompetensi pedagogik merupakan kemampuan memahami peserta didik, mendesain dan melaksanakan pembelajaran, 
melakukan evaluasi pembelajaran, serta mengembangkan potensi peserta didiknya.

2) Kompetensi Kepribadian. Kompetensi kepribadian berhubungan dengan kepribadian yang mantap, stabil, dewasa, arif, berwibawa, dapat menjadi teladan, serta berakhlak mulia.

3) Kompetensi Sosial. Kompetensi sosial merupakan kemampuan guru dalam bergaul dan berkomunikasi secara efektif dengan peserta didik dan unsur pendidik lainnya, dengan tenaga kependidikan serta masyarakat di sekitarnya.

4) Kompetensi Profesional. Kompetensi profesional ialah kemampuan guru dalam penguasaan kurikulum dan substansi keilmuannya, juga penguasaan struktur dan metodologi keilmuannya.

Jadi dapat disimpulkan bahwa guru yang kompeten adalah guru dapat melaksanakan tugasnya secara profesional. ukuran kompetensi guru tersebut meliputi (1) pemahaman terhadap peserta didik secara mendalam; (2) penguasaan materi ajar sesuai dengan disiplin ilmu maupun bahan ajar dalam kurikulum; (3) penyelenggaraan pembelajaran yang mendidik; dan (4) pengembangan kepribadian dan profesionalitas secara berkelanjutan (Naim, 2009).

Berdasarkan hasil survei yang dilakukan terhadapa alumni diketahui bahwa (1) sebahagian besar alumni telah bekerja dan bahkan mereka dapat membuka lapangan kerja sendiri; (2) bidang pekerjanaan yang diminati sebahagian alumni adalah menjadi guru. Artinya alumni bekerja sudah sesuai dengan bidang keilmuannya. Namun ketika ditelusuri lebih jauh lagi, didapati bahwa bidang pekerjaan itu adalah guru pada tingkat TK/RA/PAUD dan SD/MI. Sementara Prodi PMA sendiri mempersiapkan lulusannya untuk bekerja pada jenjang sekolah SMP/MTs/Sederajat dan SMA/SMK/MA/Sederajat; (3) sebahagian alumni bekerja pada bidang pekerjaan di luar keilmuannya, tentunya hal ini juga menjadi masalah baru yang berkaitan dengan kurikulum yang memang tidak dipersiapkan untuk dunia kerja di luar bidang pendidikan. 
Fenomena ini tentunya menjadi pekerjaan rumah bagi Prodi PMA karena kurikulum yang disusun selama ini tentunya tidak mengakomodasi kebutuhan dunia kerja di luar jalur pendidikan yang telah ditetapkannya. Maka berangkat dari hal inilah, maka peneliti terusik untuk melakukan sebuah studi untuk mencari tahu bagaimana persepsi stakeholder terhadap kompetensi alumni Prodi PMA di instansi kerjanya.

Regan, et.al. (2000) menjelaskan bahwa pendekatan kesenjangan Provu's merupakan komponen penting pada evaluasi pelatihan drivesmart (pengemudi cerdas) menggunakan CD-ROM, bahwa hasil penelitian menunjukkan bahwa program evaluasi berhasil guna dalam menyempurnakan program pengembangan selama kegiatan pembelajaran. Senada dengan Hill, E. W dan Hill, M. M. (2018) yang menjelaskan bahwa (1) hasil evaluasi internal denganmenggunakan model kesenjangan (DEM) diketahui bahwa evaluasi internal yang tidak mengikuti penggunaan sesuai dengan kriteria evaluator eksternal, (2) hasil evaluasi proses ini seharusnya dapat membangun komunikasi yang lebih cepat antara pendesain program dengan staf program. Ditambahkan oleh Mulyadi (2011) bahwa alumni fakultas teknik mesin Unhas telah bekerja sesuai bidang keahliannya sebanyak 75\% dengan masa tunggu pekerjaan pertama adalah 6 bulan. Data temuan tersebut menjadi pedoman bagi program studi dalam meningkatkan mutu layanan terhadap mahasiswa sekaligus sebagai manajemen mutu bagi pengelola.

Evaluasi merupakan prosedur yang digunakan untuk mengukur sesuatu dalam suasana dengan cara dan aturan-aturan yang sudah ditentukan. Dari hasil evaluasi biasanya diperoleh tentang atribut atau sifatsifatyang terdapat pada individu atau objek yang bersangkutan. Selain menggunakan tes, data juga dapat dihimpun dengan angket, observasi, dan wawancara atau bentuk instrumen lainnya yang sesuai (Nurhasan,2001).

Banyak sekali model-model evaluasi yang dikembangkan oleh para ahli, salah satunya adalah model evaluasi kesenjangan atau discrapancy evaluation models (DEM). Evaluasi model kesenjangan (discrepancy evaluation model) bertujuanuntuk mengetahui tingkat kesesuaian antara baku (standard) yang 
sudah ditentukan dalam program dengan kinerja (performance) sesungguhnya dari program tersebut (Fernandes, 1984). Baku adalah kriteria yang ditetapkan, sedangkan kinerja adalah hasil pelaksanaan program. Sedangkan kesenjangan yang dapat dievaluasi dalam program pendidikan meliputi:

1) Kesenjangan antara rencana dengan pelaksanaan program;

2) Kesenjangan antara yang diduga atau diramalkan akan diperoleh dengan yang benar-benar direalisasikan;

3) Kesenjangan antara status kemampuan dengan standar kemampuan yang ditentukan;

4) Kesenjangan tujuan;

5) Kesenjangan mengenai bagian program yang dapat diubah; dan

6) Kesenjangan dalam sistem yang tidak konsisten.

Oleh karena itu model evaluasi ini memiliki lima tahap yaitu desain, instalasi, proses, produk dan membandingkan. Adapun indikator untuk melakukan Discrepancy model ini adalah sebagai berikut:

a. Menentukan Standar Program.

1. Merumuskan tujuan program.

2. Menyiapkan sampel penelitian berikut kelengkapannya.

3. Merumuskan standar dalam bentuk rumusan yang dapat diukur.

b. Menentukan perbedaan antara kinerja dengan standar.

1. Meninjau kembali penetapan standar.

2. Meninjau program yang sedang berjalan.

3. Menganalisis kesenjangan antara yang direncanakan dengan yang sudah dicapai.

c. Menggunakan ketidaksesuaian sebagai bahan untuk mengubah kinerja atau standar program.

1. Mengumpulkan data dari pelaksanaan program.

2. Menganalisis data dan menetapkan tingkat output yang diperoleh.

3. Membandingkan hasil yang telah dicapai dengan tujuan yang telah ditetapkan. 
Sehingga dapat disimpulkan bahwa keterpakaian alumni di ruang publik menjadi hal yang mutlak untuk dilakukan oleh semua perguruan tinggi. Selain bermanfaat bagi perguruan tinggi untuk mengevaluasi dirinya, juga bermanfaat besar bagi pengguna alumni di masyarakat ataupun sekolah. Dan juga diketahui bahwa penggunaan model evaluasi kesenjangan (DEM) dapat menjadi salah satu alternatif dalam penetapan standar program.

\section{B. Metode}

Penelitian ini termasuk pada jenis penelitian evaluasi dengan model kesenjangan (discrepancy evaluation model). DEM memberikan informasi untuk penilaian program dan perbaikan program. Hasil yang dicapai oleh suatu komponen program dibandingkan dengan hasil yang seharusnya dicapai (kriteria). Kesimpulan didasarkan pada hasil perbandingan antara hasil dengan kriteria yang ditetapkan, sehingga dapat diketahui ada tidaknya kesenjangan (discrepancy) antara kriteria yang ditetapkan dengan hasil yang dicapai.

Provus mendefinisikan DEM sebagai proses dari (1) menentukan standar program; (2) menentukan perbedaan antara kinerja dengan standar; (3) menggunakan ketidaksesuaian sebagai bahan untuk mengubah kinerja atau standar program (Fitzpatrick, Sanders \& Worthen, 2004). Panduan untuk mengevaluasi program Prodi PMA IAIN Langsa menggunakan standar evaluasi program dari Guidelines for Performance Based Professional School Counselor Evaluation (Missouri Department of Elementary and Secondary Education, 2000).

Penjelasan di atas, dapat dirangkum dalam tiga tahapan saja. Untuk itu secara terperinci data hasil penelitian akan dianalisis dengan menggunakan model DEM (Descrapancy Evaluation Models). Model ini membagi persoalan menjadi tiga (3) bagian. Namun peneliti menjabarkan ketiga bagian tersebut menjadi subbab sehingga ulasannya menjadi lebih terperinci, yakni desain program (merumuskan tujuan program, menyiapkan sampel penelitian berikut kelengkapannya, merumuskan standar dalam bentuk rumusan yang dapat diukur), menentukan perbedaan antara kinerja dengan standar 
(meninjau kembali penetapan standar, meninjau program yang sedang berjalan, menganalisis kesenjangan antara yang direncanakan dengan ketercapaian), menggunakan ketidaksesuaian sebagai bahan untuk mengubah kinerja atau standar program (mengumpulkan data dari pelaksanaan program, menganalisis data dan menetapkan tingkat output yang diperoleh, membandingkan hasil yang telah dicapai dengan tujuan yang telah ditetapkan)

\section{Hasil dan Pembahasan}

Berdasarkan hasil analisis data maka diperoleh hasil sebagai berikut:

1. Menentukan Standar Program.

Standar program evaluasi kesenjangan ini adalah untuk mendeskripsikan:

1) Kesesuaian kurikulum Prodi PMA FTIK IAIN Langsa dengan kurikulum sekolah atau kebutuhan sekolah.

2) Persepsi stakeholder terhadap kompetensi alumni Prodi PMA FTIK IAIN Langsa.

a) Merumuskan tujuan program. Tujuan program evaluasi kesenjangan disesuaikan dengan standar program yang telah ditetapkan sebelumnya yaitu:

$\checkmark$ Meninjau kesesuaian kurikulum Prodi PMA dalam memenuhi kebutuhan dan perubahan kurikulum sekolah yang begitu cepat.

$\checkmark$ Mengetahui persepsi stakeholder terhadap kompetensi alumni Prodi PMA yang bekerja pada instansi yang dipimpinnya.

b) Menyiapkan sampel penelitian berikut kelengkapannya.

1) Sampel penelitian ditetapkan sebanyak 81 alumni Prodi PMA angkatan 2011 sampai angkatan 2018 yang tersebar pada tiga Kabupaten dan Kota yaitu Kabupaten Aceh Tamiang dan Aceh Timur, serta Kota Langsa.

2) Untuk responden yang tidak terjangkau dalam penelitian maka dilakukan juga penyebaran kuesioner secara online dengan 
lamanhttp://bit.ly/keu-user-pma ditujukan kepada stakeholder.

c) Merumuskan standar dalam bentuk rumusan yang dapat diukur. Adapun rumusan standar program evaluasi kesenjangan ini adalah:

(a)Berapa persentase alumni yang bekerja sesuai bidang keilmuan matematika?

(b) Bagaimana kompetensi alumni Prodi PMA menurut persepsi stakeholder?

2. Menentukan perbedaan antara kinerja dengan standar.

a) Meninjau kembali penetapan standar. Standar program evaluasi yangditetapkan meliputi dua (2) hal yakni:

1. Persepsi stakeholder terhadap kompetensi alumni Prodi PMA. Pengumpulan data dilakukan dengan mengunjungi sekolah dan menjumpai stakeholder dan bagi sekolah yang tidak terjangkau dalam penelitian maka penjaringan data dilakukan dengan penyebaran kuesioner online. Beberapa data yang diperoleh:

$\checkmark$ Alumni Prodi PMA tersebar pada beberapa sektor pendidikan dan non pendidikan mulai dari jenjang TK/RA/PAUD, SD, SMP, MTs, SMA, dan MA, Bank, Security, Wirausaha, dan Karyawan Swasta.

$\checkmark$ Dilakukan analisis secara mendalam mengenai kompetensi alumni sesuai dengan kebutuhan dunia kerja mereka.

b) Meninjau program yang sedang berjalan. Kegiatan evaluasi program ini dilakukan dengan mencocokkan data yang diperoleh dari wawancara dengan Ketua Prodi, Sekretaris Prodi, Alumnidan Stakeholder.

c) Menganalisis kesenjangan antara yang direncanakan dengan yang sudah dicapai. Beberapa kesenjangan yang diperoleh dari hasil evaluasi Prodi PMA FTIK IAIN Langsa adalah: 
$\checkmark$ Terdapat masalah pada sebahagian alumni ketika mereka memasuki dunia kerja, terkait dengan kompetensi atau keterampilan yang sebagian tidak dipelajari semasa kuliah hal ini terkhusus pada alumni yang bekerja di luar bidang pendidikan.

$\checkmark$ Pada alumni yang bekerja di bidang pendidikan, stakeholder menyarankan adanya perubahan pada beberapa mata kuliah yang terkait langsung dengan pendidikan sekolah, di antaranya pemahaman lebih mendalam tentang peserta didik, ICT, kewirausahaan, karya ilmiah, sehingga alumni mampu bersaing dengan alumni dari perguruan tinggi lain.

3. Menggunakan ketidaksesuaian sebagai bahan untuk mengubah kinerja atau standar program.

a. Mengumpulkan data dari pelaksanaan program.

1) Data dikumpulkan dengan menyebarkan kuesioner, melakukan wawancara, dan dokumentasi terkait tujuan penelitian ini.

2) Pengumpulan data dilakukan hanya pada tiga (3) Kabupaten/Kota, yakni Kabupaten Aceh Tamiang dan Aceh Timur juga Kota Langsa.

b. Menganalisis data dan menetapkan tingkat output yang diperoleh. Data tersebut disesuaikan dengan rumusan standar, yakni: Persentase alumni yang bekerja sesuai bidang keilmuan adalah 71,60\% atau setara dengan 58 orang dari 81 alumni yang menjadi responden penelitian. Yang tersebar pada tiga level pendidikan yaitu dasar (SD), menengah (SMP) dan atas (SMA). Sementara 23 orang atau 28,34\% bekerja pada sektor di luar bidang pendidikan.

c. Membandingkan hasil yang telah dicapai dengan tujuan yang telah ditetapkan. Berdasarkan hasil analisis diketahui bahwa (1) sebahagian alumni Prodi PMA dinilai mampu bekerja dengan baik dan mampu menjawab berbagai tantangan serta dinamika pada dunia kerja, namun ada juga alumni yang masih "kurang kompeten" sehingga hal ini 
menjadi tugas rumah bagi Prodi PMA dalam menyusun kurikulum untuk lebih memperhatikan dan mampu menghasilkan lulusan yang siap bekerja dan mampu beradaptasi dengan perkembangan dan perubahan di dunia kerja.

\section{Kesimpulan}

Kesesuaian bidang pekerjaan dengan dengan ijazah alumni dari jumlah sampel penelitian sebanyak 81 orang, diperoleh $71,60 \%$ atau 58 alumni bekerja pada sektor pendidikan dan 28,40\% atau 23 alumni bekerja pada sektor lain seperti Wirausaha, Pegawai Bank, Satpam, dan sebagainya. Terkait dengan penilaian user/stakeholder terhadap kapabilitas mahasiswa Program Studi Pendidikan Matematika FTIK IAIN Langsa adalah sebahagian alumni mampu bekerja dengan baik dan mampu menjawab berbagai tantangan serta dinamika pada dunia kerja, namun ada juga alumni yang masih "kurang kompeten" sehingga diharapkan Prodi PMA lebih memperhatikan dan mampu menghasilkan lulusan yang siap bekerja.

\section{E. Saran}

Beberapa saran yang direkomendasikan dari hasil penelitian ini adalah bahwa perubahan kurikulum merupakan satu hal yang tak dapat dipungkiri. Sehingga perubahan itu dilakukan sesuai dengan analisis kebutuhan masyarakat, sekolah, dan lapangan kerja lain. Penyusunan kurikulum bukan hanya sekadar input teori dibangku kuliah saja tetapi dapat dipraktikkan di lapangan dengan kata lain kurikulum disusun sesuai dengan kebutuhan pasar. Dan perguruan tinggi harus mampu bergerak dengan cepat untuk menjawab setiap perubahan kurikulum di sekolah. Pentingnya melakukan workshop tentang kurikulum Prodi PMA dengan melibatkan stakeholder serta instansi pendidikan bahkan instansi di luar sektor pendidikan untuk mendata kebutuhan pasar kerja. Perlu melakukan sosialisasi terkait dengan perubahan kurikulum kepada pengguna alumni, instansi pemerintah, dan instansi terkait lainnya. 


\section{DAFTAR PUSTAKA}

Buttram, Joan L. and Robert W. Covert. The Discrepancy Evaluation Model: A Systematic Approach For The Evaluation of Career Planning and Placement Programs. Document ED143683

Cresweel, J. (2015). Riset Pendidikan: Perencanaan, Pelaksanaan, dan Evaluasi Riset Kualitatif dan Kuantitatif. Cetakan Pertama. Yogyakarta: Pustaka Pelajar.

Dakir. (2004) Perencanaan dan Pengembangan Kurikulum. Jakarta: Rineka Cipta.

Djohar. (2006). Guru, Pendidikan dan Pembinaannya (Penerapannya dalam Pendidikan dan Undang-Undang Guru). Yogyakarta: Sinar Grafika.

Edwards, R., \& Holland, J. (2013). What is qualitative interviewing? In G. Crow (Ed.), "What is?" Research Methods series. (online) https://eric.ed.gov/?id=ED143683. London \& New York: Bloomsbury Academic.

Miles dan Huberman. Terjemahan Rohidi. T.R (2009). Analisis Data Kualitatif. Jakarta: Universitas Indonesia (UI-Press).

Mulyadi, Studi Pelacakan Alumni Program Studi Teknik Industri Jurusan Mesin Fakultas Teknik Unhas. (Proseding, Volume 5, Desember 2011, ISBN 978-979-127255-0-6).

Mulyasa, E. (2004). Kurikulum Berbasis Kompetensi. Bandung: Remaja Rosdakarya Offset.

Naim, Ngainun. (2009). Menjadi Guru Inspiratif: Memberdayakan dan Mengubah Jalan Hidup Siswa. Yogyakarta: Pustaka Pelajar.

Poerwadarminta. (2003). Kamus Umum Bahasa Indonesia. Jakarta: Balai Pustaka.

Regan, et. al. (2000) simulator-based evaluation of the DriverSmart novice driver CD-ROM training product. In proceedings of the Road Safety Research, Policing and Education 2000 Conference. Brisbane, Australia.

Undang-Undang Nomor 14 Tahun 2005 Tentang Guru dan Dosen. http://peraturan.go.id/uu/nomor-14-tahun-2005.html. 
Undang-Undang Nomor 16 Tahun 2007 Tentang Standar Kompetensi Guru.http://peraturan.go.id/pp/nomor-16-tahun-2007-

11e44c4ea6e1ddd08e1c313231353431.html 